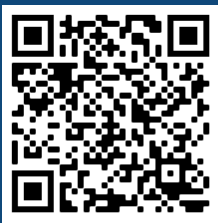

Keywords:

Brazilian rosewood Forest conservation

Historic:

Received 16/06/2020 Accepted 18/09/2020

Correspondence: adelsonlemes@yahoo.com.br
Adelson Lemes da Silva Júnior ${ }^{\mathrm{la}}$, Rafael Lara Rezende Cabral ${ }^{\mathrm{lb}}$, Lara Sartori ${ }^{\mathrm{lc}}$, Lucimara Cruz de Souza ${ }^{\text {ld }}$, Fábio Demolinari de Miranda ${ }^{\text {ee }}$, Marcos Vinicius Winckler Caldeira ${ }^{2 a}$, Sarah Ola Moreira ${ }^{3 a}$, Tiago de Oliveira Godinho ${ }^{4 a}$

\section{EVALUATION OF DIVERSITY AND GENETIC STRUCTURE AS STRATEGIES FOR CONSERVATION OF NATURAL POPULATIONS OF Dalbergia nigra (Vell.)} Allemão ex Benth.

SILVA JÚNIOR, A. L. da; CABRAL, R. L. R.; SARTORI, L.; SOUZA, L. C. de; MIRANDA, F. D. de; CALDEIRA, M. V. W.; MOREIRA, S. O.; GODINHO, T. de O. Evaluation of diversity and genetic structure as strategies for conservation of natural populations of Dalbergia nigra (vell.) Allemão ex Benth. CERNE, v. 26, n. 4, p.435-443, 2020.

\section{HIGHLIGHTS}

The ISSR molecular markers were effective to estimate diversity and genetic structure.

There is moderate to high genetic diversity for $D$. nigra.

Most of the genetic diversity was influenced by individuals from Flona of Pacotuba.

The evaluated populations are structured.

\section{ABSTRACT:}

The evaluation of diversity and genetic structure allows us to verify with precision the effect of evolutionary and anthropic processes on species. The objective of this research was to evaluate the divergence and the genetic structure of two natural populations of Dalbergia nigra, using molecular markers Inter Simple Sequence Repeats (ISSR). Leaf samples were collected from two populations, located in the National Forest of Pacotuba and the Private Natural Heritage Reserve of Cafundó. Eight ISSR primers were used, which resulted in 97 bands, with $68.04 \%$ of polymorphism. Based on the joint data, the values of 0.33 for the Nei index $\left(\mathrm{H}^{*}\right)$ and 0.50 for the Shannon index (I*) indicated moderate to high genetic diversity, being influenced by the presence of genetically dissimilar individuals in the National Forest of Pacotuba. Most of the genetic divergence was intrapopulational $(85.96 \%)$, with moderate differentiation between populations $\left(\Phi_{\text {ST }}=0.1404\right)$. The estimated historical gene flow between the fragments was low $\left(\mathrm{N}_{\mathrm{m}}=3.2 \mathrm{I}\right)$ when compared with results from other tree species, and the genetic structuring analysis separated the populations into two groups, corresponding to the two populations evaluated. The results indicate a small genetic share among populations, however, populations are becoming structured. The satisfactory levels of genetic diversity benefit the use of the trees as matrixes for programs of restoration and recovery of degraded areas, connectivity of landscapes, and sustainable use of forest resources.

'Federal University of Espirito Santo, Alegre, Espírito Santo, Brasil. ORCID: 0000-0003-0940-8398a , 0000-000 I6535-3809b, 0000-0002-8776-3734c, 0000-000 I-5795-7960 d, 0000-0002-2344-4398e

${ }^{2}$ Federal University of Espirito Santo, Jerônimo Monteiro, Espírito Santo, Brasil. ORCID: 0000-0003-469|-989|a ${ }^{3}$ Instituto Capixaba de Pesquisa, Assistência Técnica e Extensão Rural, Linhares, Espírito Santo, Brasil. ORCID: 00000003-0659-6725

${ }^{4}$ Vale, Linhares, Espírito Santo, Brasil. ORCID: 0000-000 I-6249-6054ª 


\section{INTRODUCTION}

Environmental and anthropic factors influence the diversity patterns of plant species. The loss and fragmentation of habitats associated with selective logging have been considered as the main threats to the conservation, diversity, and genetic structure of tropical forests (Macedo et al., 2012; Tapia-Armijos et al., 20I5). The Atlantic Forest is a classic example of how anthropic modification has resulted in isolation and reduction of previously connected and wellestablished populations (Ribeiro et al., 2016).

Currently, it is estimated that only $6 \%$ of the Atlantic Forest is protected by Conservation Units (CU's) (Campanili and Schaffer, 20I0), in addition, the intense fragmentation of habitats has even altered the ecological dynamics of protected areas, impairing the maintenance of species. For the existing vegetation to be conserved, maintenance and proper management of the remaining individuals are necessary (Martins et al., 2016). The determination of management and conservation actions requires knowledge of the ecological aspects and genetic composition of species, such as the diversity and genetic structure of populations (Hamrick, 20I2; Gois et al., 20I8).

The species Dalbergia nigra (Vell.) Allemão ex Benth., popularly known as Brazilian rosewood, is a tree that stands out for its ecological and economic potential. Because it has an abundance of seeds capable of colonizing the most diverse environments, it can be widely used in the restoration and recovery of the degraded environment, also helping in the soil nutritional condition once it is a nitrogen-fixing species. Also, the high-quality wood in terms of durability, handling, and commercialization, promote $D$. nigra as the best Brazilian wood (Martinelli and Moraes, 20I3).

Dalbergia nigra is endemic to Brazil with a wide distribution in the Atlantic Forest (Lima, 20I5). Due to the substantial biome fragmentation and the intense predatory exploration that occurred in the past, mainly from the selective cutting of the largest individuals, it is estimated that $30 \%$ of the original populations of this species were lost, causing a decrease in its genetic diversity (Martinelli and Moraes, 2013). For these reasons, $D$. nigra is classified as vulnerable on the Red List of Threatened Species of International Union for Conservation of Nature (IUCN) (IUCN, 2020).

The understanding of the effect of environmental disturbances on the genetic divergence of $D$. nigra will allow us to establish strategies for its conservation in situ and ex situ. Information on the distribution of genetic diversity among and within populations contributes effectively to the conservation of genetic resources (Templeton, 20 I I; Potter et al., 2017).
One of the widely used tools for the quantification of these parameters is the molecular markers (Filippos, 2016). Among them, the dominant markers, such as the Inter Simple Sequence Repeat (ISSR), have been used successfully in the quantification of diversity and genetic structure in the genus Dalbergia, allow detecting the genetic variability among the evaluated individuals (Wang et al., 20 I0; Ginwal et al., 20I I; Yulita et al., 2020).

This research aimed to evaluate the diversity and genetic structure of two natural populations of $D$. nigra in Conservation Units. This information will be important to define strategies for the management of CU's and conservation of the species, in addition to the identification of future matrixes for use in the restoration and recovery of degraded areas, connectivity of landscapes and sustainable use of forest resources.

\section{MATERIAL AND METHODS}

\section{Sampling strategy}

The $D$. nigra samples were collected in two Conservation Units (CU's) located in the Southern Espírito Santo State: The National Forest of Pacotuba, with 449.72 ha (Flona of Pacotuba - 204' S; $41^{\circ}$ I7' O), and the Private Natural Heritage Reserve of Cafundó, with 517 ha (PNHR Cafundó - 2043' S; 4113' O). The studied areas are $4 \mathrm{~km}$ distant from each other, and both present the Seasonal Semideciduous Forest vegetation type. These CU's were selected due to their representativeness of environmental preservation in the region and, historically, have suffered environmental disturbances such as selective logging, local fires, and agricultural activities (ICMBIO, 20I I) (Figure I).

Leaf samples were collected from $24 \mathrm{D}$. nigra adult trees, 12 individuals from each population. The sampling carried out taking into account the distribution of populations and the geographical distance of at least 100 $\mathrm{m}$ between individuals, avoiding kinship (Sebbenn, 2002).

\section{DNA extraction and genotyping via ISSR}

The genomic DNA was extracted by the CTAB method developed by Doyle and Doyle (1990), adjusting the concentrations to $1 \%$ polyvinylpyrrolidone (PVP) and $2 \%$ cetyltrimethylammonium bromide (CTAB). The determination of the concentration and purity values of the extracted DNA was estimated by spectrophotometry performed with the NanoDrop 2000C equipment (Thermo Scientific), adopting the ( $\left.1.80 \leq \mathrm{A}_{260} / \mathrm{A}_{280} \geq 2.00\right)$ ratio as quality criteria (Aguilar et al., 2016).

To perform the PCR assays, aliquots of the individuals' DNA were used at a final concentration of $10 \mathrm{ng} \cdot \mu \mathrm{L}^{-1}$ with 


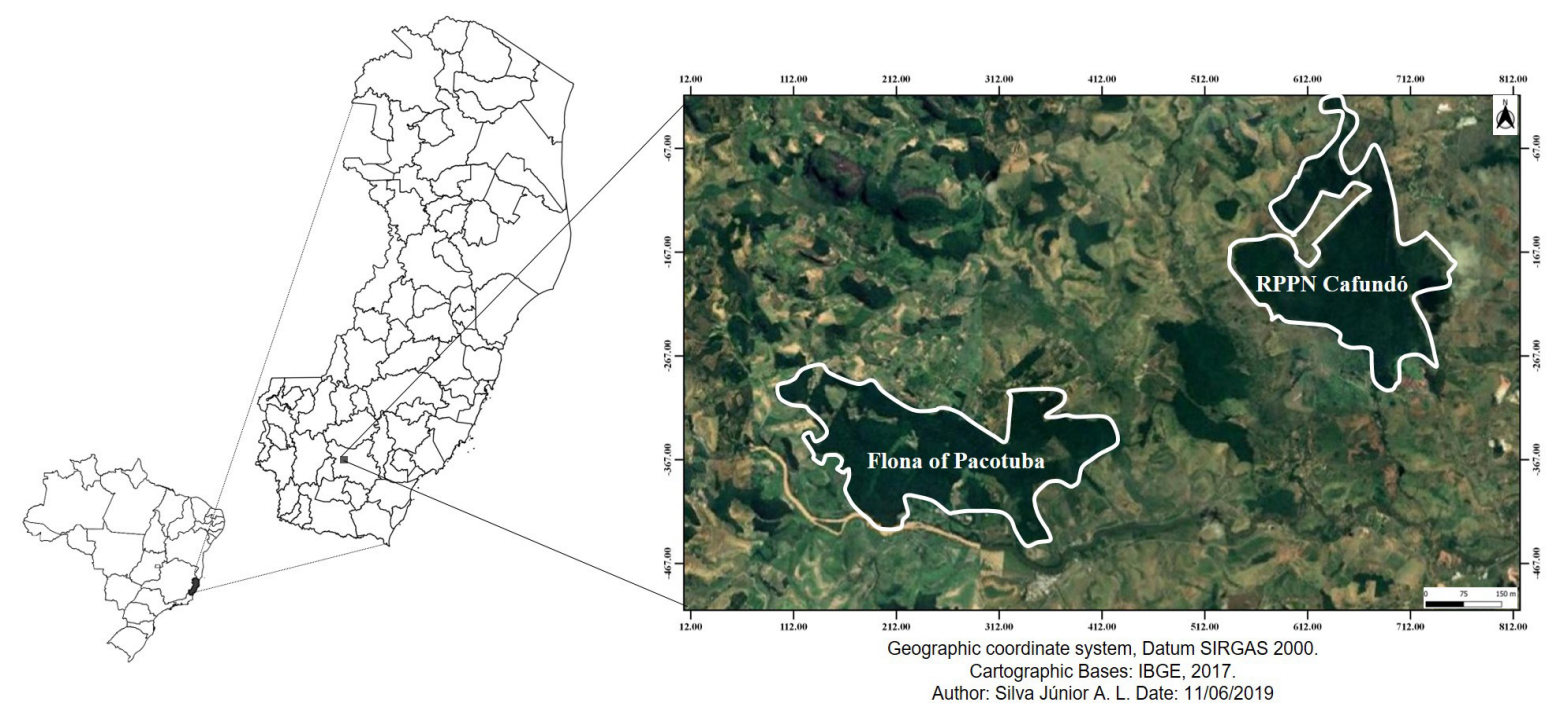

FIGURE I Location map of the studied areas, showing the Conservation Units: Flona of Pacotuba and PNHR Cafundó.

eight ISSR primers (UBCs 807; 809; 8I0; 8II; 8I 2; 8I8; 822 and 836), developed by the University of British Columbia. The total reaction volume was $20 \mu \mathrm{L}$, containing: IX Buffer (10 mM Tris-HCL (pH 8.5) and $50 \mathrm{mM} \mathrm{KCl}), \mathrm{MgCl}_{2}(2.5$ $\mathrm{mM})$, dNTP (I mM), primer $(0.2 \mu \mathrm{M})$, I unit of Taq DNA polymerase and $50 \mathrm{ng}$ of genomic DNA.

The fragment amplifications were performed in a thermocycler (Applied Biosystems, model Veriti), with initial denaturation step of $5 \mathrm{~min}$ at $94^{\circ} \mathrm{C}$, followed by 35 denaturation cycles $\left(94{ }^{\circ} \mathrm{C}\right.$ for $45 \mathrm{sec}$ ), annealing $\left(52{ }^{\circ} \mathrm{C}\right.$ for $\left.45 \mathrm{sec}\right)$ and extension $\left(72{ }^{\circ} \mathrm{C}\right.$ for $\left.90 \mathrm{sec}\right)$ and a final elongation of $72{ }^{\circ} \mathrm{C}$ for $7 \mathrm{~min}$. Subsequently, the amplification products were separated by electrophoresis on a $2 \%$ agarose gel, at an electrical charge of 100 volts for 4 hours. The gels were submerged in ethidium bromide solution $(0.50 \mu \mathrm{g} / \mathrm{mL})$ for $30 \mathrm{~min}$, photographed under UV light on a photocumenter (ChemiDoc MP Imaging System - Bio Rad) and separated according to the molecular weight by the 100 bp ladder marker (Ludwig Biotechnology).

\section{Statistical analysis}

Amplification result was converted into a binary matrix. Each primer was evaluated for the total number of bands (TNB), the number of polymorphic bands (NPB), percentage of polymorphic bands (PPB) and size variation of the fragments generated in base pairs (SVF). The polymorphic information content (PIC) was also accurate according to Weiler et al. (2010).

To estimate genetic diversity among individuals and between populations, the number of observed alleles $\left(A_{0}\right)$, number of effective alleles $\left(A_{e}\right)$, genetic diversity of $\mathrm{Nei}\left(\mathrm{H}^{*}\right)$ and Shannon diversity index (I*) were estimated. The average number of migrants per generation $\left(\mathrm{N}_{\mathrm{m}}\right)$ was also calculated, which estimates the gene flow between populations. All of these statistical parameters were calculated using the Popgene software version 3.2 (Yeh and Boyle, 1997).

From the binary matrix, the genetic dissimilarity matrix was generated through the arithmetic complement of the Jaccard coefficient. The genetic dissimilarity was used to make the dendrogram, developed by the method of grouping unweighted arithmetic means (UPGMA), with a cut-off point following the proposed by Mojema (1977), with $k=1.25$. The consistency checking between the values matrix and the formed clusters was determined by the cophenetic correlation coefficient (CCC). For these analyzes, the Genes software (Cruz, 2016) was used the dendrogram was generated by the software $R$ ( $R$ Development Core Team, 2016), associated with the use of vegan (Oksanen et al., 20I8), cluster (Maechler et al., 2019), dendextend (Galili et al., 2020), factorextra (Kassambara and Mundt, 2020), ggpubr (Kassambara, 2020), cowplot (Wilke, 2019), gridExtra (Auguie and Antonov, 2017).

The analysis of molecular variance (AMOVA) was performed using the software Arlequin version 3.5 (Excoffier and Lischer, 2010). However, the number of groups $(k)$ generated for the study sample, was obtained by the Bayesian approach carried out in the program Structure 2.3.3 (Falush et al., 2007). For the structuring analysis, the following parameters were established: for each $k$ value, 20 runs were carried out, with a preestablished number of groups, with a $k$ value ranging from I to 5, according to the proposed by Evanno et al. (2005), and I0.000 Monte Carlo simulations via Markov Chains (MCMC). The data generated from this analysis were plotted in the Structure Harvester software (Earl 
and Vonholdt, 20/2), to define the most likely $k$ value according to the $\Delta k$ method (Evanno et al., 2005). After selecting the best $k$, a consensus of the 20 interactions was made using the Clumpp software (Jakobsson and Rosenberg, 2007) and then the graphic result was obtained using the Distruct software (Rosenberg, 2004).

\section{RESULTS}

\section{Descriptive analysis}

Genotyping generated 97 bands in total, of which 66 were polymorphic, corresponding to $68 \%$ polymorphism. The UBC 809 primer presented the highest number of total and polymorphic bands, while the UBC 822 primer presented the lowest values. The UBC 809 primer also obtained the highest percentage of polymorphic bands (75\%), meanwhile, UBC 807 presented the lowest PPB (54.54\%) (Table I).

Markers efficiency and genetic diversity

For the loci, we observed that the averages of the polymorphic information content (PIC), which measures the efficiency of the markers, were similar for both populations ( 0.36 and 0.37$)$, as well as for the joint data (0.34) (Table 2).

TABLE I ISSR primers selected for Dalbergia nigra, including sequence (5'-3') for each primer, the total number of bands (TNB), number of polymorphic bands (NPB), percentage of polymorphic bands (PPB) and size variation of the fragments (SVF) determined by a 100 bp molecular weight marker.

\begin{tabular}{cccccc}
\hline Primer & Sequence (5'-3') & TNB & NPB & PPB (\%) & SVF (max-min) \\
\hline UBC 807 & AGAGAGAGAGAGAGA GT & 11 & 6 & 54.54 & $1300-300$ \\
UBC 809 & AGAGAGAGAGAGAGA GG & 16 & 12 & 75.00 & $1300-370$ \\
UBC 810 & GAGAGAGAGAGAGAG AT & 13 & 8 & 61.53 & $1500-350$ \\
UBC 8II & GAGAGAGAGAGAGAG AC & 13 & 9 & 69.23 & $1500-190$ \\
UBC 812 & GAGAGAGAGAGAGAG AA & 15 & 11 & 73.33 & $1400-400$ \\
UBC 8I8 & CACACACACACACAC AG & 11 & 8 & 72.72 & $1150-450$ \\
UBC 822 & TCTCTCTCTCTCTCT CA & 7 & 4 & 57.14 & $1300-700$ \\
UBC 836 & AGAGAGAGAGAGAGA GYA & 11 & 8 & 72.72 & $1300-390$ \\
\hline AVERAGE & - & - & - & 68.04 & - \\
\hline TOTAL & - & 97 & 66 & - & - \\
\hline
\end{tabular}

* $\mathrm{A}=$ Adenine; $\mathrm{T}=$ Thymine; $\mathrm{C}=$ cytosine; $\mathrm{G}=$ Guanine and $\mathrm{Y}=(\mathrm{C}$ or $\mathrm{T})$.

TABLE 2 Polymorphic information content (PIC), number of observed alleles $\left(A_{o}\right)$ and effective $\left(A_{e}\right)$, and genetic diversity estimated by the Nei $\left(H^{*}\right)$ and Shannon $(I *)$ indices estimated for loci, populations, and joint data.

\begin{tabular}{|c|c|c|c|c|c|c|c|c|c|c|c|c|c|c|c|}
\hline \multirow{2}{*}{ Loci } & \multicolumn{5}{|c|}{ Flona of Pacotuba } & \multicolumn{5}{|c|}{ PNHR Cafundó } & \multicolumn{5}{|c|}{ Joint Data } \\
\hline & $\mathrm{PIC}$ & $\mathrm{A}_{0}$ & $A_{e}$ & $\mathrm{H}^{*}$ & I* & $\mathrm{PIC}$ & $A_{0}$ & $A_{e}$ & $\mathrm{H}^{*}$ & I* & $\mathrm{PIC}$ & $A_{0}$ & $A_{e}$ & $\mathrm{H}^{*}$ & I* \\
\hline UBC 807 & 0.46 & 1.83 & 1.73 & 0.38 & 0.54 & 0.40 & 1.83 & 1.58 & 0.33 & 0.49 & 0.40 & 2.00 & 1.70 & 0.40 & 0.58 \\
\hline UBC 809 & 0.39 & $\mathrm{I} .83$ & 1.58 & 0.32 & 0.47 & 0.34 & 1.58 & $\mathrm{I} .33$ & 0.20 & 0.30 & 0.33 & 2.00 & 1.50 & 0.30 & 0.46 \\
\hline UBC 810 & 0.34 & 1.75 & 1.48 & 0.25 & 0.38 & 0.34 & 1.87 & 1.49 & 0.30 & 0.45 & 0.33 & 2.00 & 1.55 & 0.33 & 0.50 \\
\hline UBC 8II & 0.34 & 2.00 & 1.46 & 0.26 & 0.40 & 0.39 & 1.77 & 1.54 & 0.31 & 0.45 & 0.31 & 2.00 & 1.53 & 0.31 & 0.48 \\
\hline UBC 812 & 0.33 & 2.00 & 1.56 & 0.33 & 0.50 & 0.36 & 1.81 & 1.49 & 0.29 & 0.44 & 0.34 & 2.00 & 1.56 & 0.34 & 0.51 \\
\hline UBC 818 & 0.36 & 2.00 & 1.63 & 0.36 & 0.54 & 0.37 & 1.25 & 1.15 & 0.09 & 0.14 & 0.33 & 2.00 & 1.57 & 0.33 & 0.51 \\
\hline UBC 822 & 0.33 & 1.75 & 1.39 & 0.25 & 0.38 & 0.43 & 1.75 & 1.58 & 0.32 & 0.46 & 0.33 & 2.00 & 1.57 & 0.33 & 0.50 \\
\hline UBC 836 & 0.40 & 1.87 & 1.63 & 0.35 & 0.52 & 0.39 & 1.75 & 1.49 & 0.29 & 0.43 & 0.36 & 2.00 & 1.61 & 0.36 & 0.53 \\
\hline AVERAGE & 0.36 & 1.87 & 1.55 & 0.31 & 0.46 & 0.37 & 1.70 & 1.45 & 0.26 & 0.39 & 0.34 & 2.00 & 1.57 & 0.33 & 0.50 \\
\hline
\end{tabular}




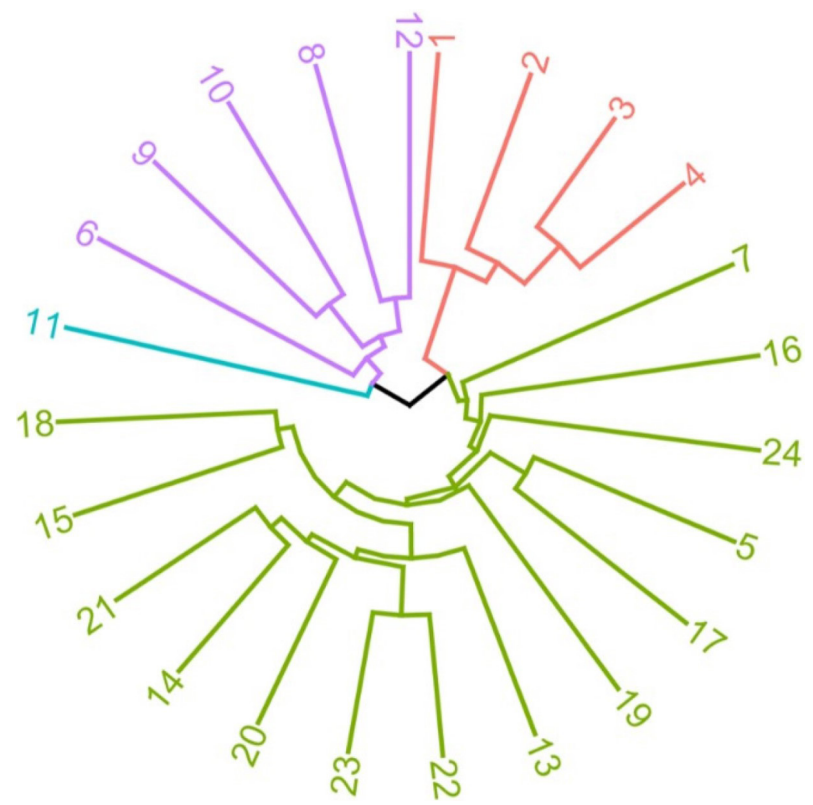

FIGURE 2 Dendrogram obtained by the UPGMA method, representing the genetic dissimilarity among 24 individuals of Dalbergia nigra species. The numbers I to 12 correspond to Flona of Pacotuba population and 13 to 24 are those from PNHR Cafundó. Cutoff point (Pc): 0.473 .

estimate of $\Phi_{S T}=0.1404$, which means that only $14.04 \%$ of the total genetic variation was between populations, while the largest variation (85.96\%), was intrapopulational (Table 3). The estimated $\mathrm{N}_{\mathrm{m}}$ for the populations was 3.21 .

TABLE 3 Analysis of molecular variance (AMOVA) between and within Dalbergia nigra populations.

\begin{tabular}{ccccc}
\hline $\begin{array}{c}\text { Variation } \\
\text { source }\end{array}$ & $\begin{array}{c}\text { Degrees } \\
\text { of freedom }\end{array}$ & $\begin{array}{c}\text { Sum of } \\
\text { squares }\end{array}$ & $\begin{array}{c}\text { Components of } \\
\text { Variance }\end{array}$ & $\begin{array}{c}\text { Variation } \\
(\%)\end{array}$ \\
\hline $\begin{array}{c}\text { Between } \\
\text { populations } \\
\text { Within }\end{array}$ & 1 & 23.25 & 1.64 & 14.04 \\
$\begin{array}{c}\text { populations } \\
\text { Total }\end{array}$ & 16 & 161.25 & 10.07 & 85.96 \\
\hline$\Phi_{\text {ST }}=0.1404$ & 47 & 184.50 & 11.72 & \\
\hline
\end{tabular}

The structuring carried out in the scope of species obtained by the Bayesian approach, defined the most likely number of $k$ clusters in two $(k=2)$ (Figure 3).

\section{DISCUSSION}

\section{Performance of ISSR markers}

The use of ISSR markers was efficient in identifying polymorphisms among the individuals evaluated. The observed PPB value was close to the obtained by Ribeiro

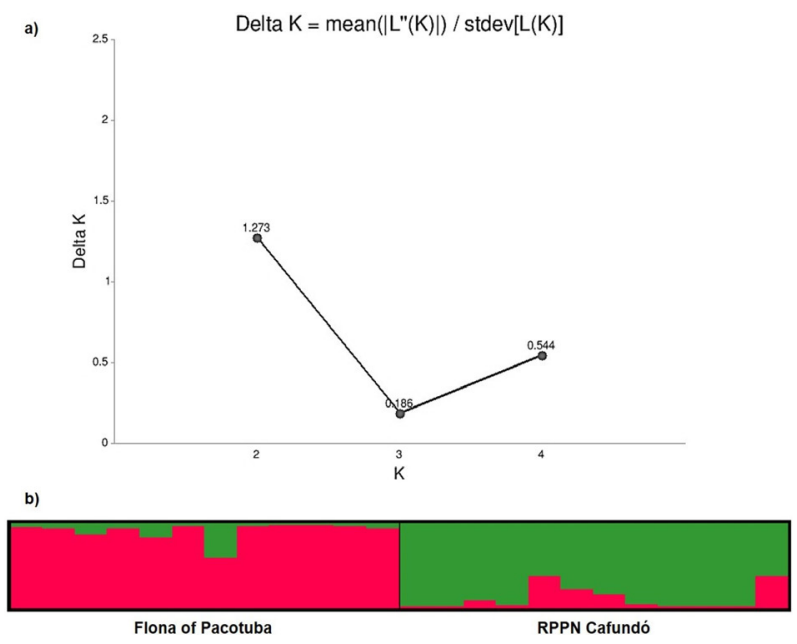

FIGURE 3 Population structure analysis (Bayesian approach) for two populations of Dalbergia nigra: Flona of Pacotuba $(N=12)$ and PNHR Cafundó $(N=12)$. a) Relationship of $\Delta k$ values for each $k$ value. b) Genetic structure of $D$. nigra populations (indicated by different colors).

et al. (2005) who found $73 \%$ polymorphism, based on allozyme markers for three $D$. nigra populations located in of the Rio Doce State Park, Minas Gerais state. Juchum et al. (2007) reported $39 \%$ polymorphism using RAPD markers for two populations, one located at PNHR Veracel and the other at Brazilwood Ecological Station, Porto Seguro, Bahia state. The history of disturbance in the areas mentioned in previous studies is similar to that evidenced in Flona de Pacotuba and PNHR Cafundó. Therefore, the differences found can be justified by the number of populations evaluated and also by the type of marker.

The PIC values corroborate with the PPB results. According to Chesnokov and Artemyeva (2015), for dominant markers, the PIC value between 0 and 0.25 is classified as not very informative; from 0.25 to 0.45 , is moderately informative; and from 0.45 to 0.50 is highly informative. This classification determines that the markers used in this study, for individual populations, and the joint data, were moderately informative. However, the data obtained were sufficient to estimate the genetic diversity of $D$. nigra in natural populations.

\section{Genetic diversity}

The number of alleles $\left(A_{0}\right.$ and $\left.A_{e}\right)$ and the genetic diversity $\left(\mathrm{H}^{*}\right.$ and $\left.\mathrm{I}^{*}\right)$ estimated for the individual populations, were higher for the Flona of Pacotuba. Such results indicate that this population has a better distribution of alleles and, consequently, a greater genetic diversity. This fact can be directly related to 
strategies carried out by the Conservation Unit (CU), such as fire prevention measures or selective cutting, the georeferencing of trees with some degree of threat, seed collection, and production of seedlings implanted in the $\mathrm{CU}$ itself. It should be noted that the PNHR Cafundó, despite having less genetic diversity, also represents an important source of genetic variability, having exclusive alleles, evidenced by the increase in the values of the parameters $A_{o}, A_{e}, H^{*}$ and $I^{*}$ of the joint data (Table 2).

For the joint data, the number of observed alleles $\left(A_{\circ}\right)$ is equivalent to what is expected for diploid species, two alleles per loci. The average $A_{e}$ (I.57) indicated a good distribution of alleles between populations. The results of $\mathrm{H}^{*}$ and $\mathrm{I}^{*}$ for the joint data revealed moderate to high genetic diversity.

The values of $\mathrm{H}^{*}$ and $\mathrm{I}^{*}$ found in this study were higher than those found for species of the genus Dalbergia, using ISSR markers. In studies with the species $D$. sissoo, mean values of 0.27 were found for $\mathrm{H}^{*}$ and $0.4 \mathrm{I}$ for I* (Wang et al., 2010), while for D. latifolia species, those values were 0.16 and 0.25 , respectively (Yulita et al., 2020).

The satisfactory levels found for the genetic diversity of the species indicate that it has managed to keep up with the disturbances generated by its predatory exploitation and the fragmentation of natural populations, having as a positive factor the fact that they are located in CU's, which restrict selective cutting. Studies with vulnerable and threatened species, such as $D$. nigra, demonstrated that these species can restore their population, if there is genetic diversity, knowledge and, control over the genetic structure in the occurrence areas (Martinelli and Moraes, 20I3; Souza et al., 2017; Mangaravite et al., 2019). This is even more relevant because $D$. nigra is an allogamous species, that is, it preferably performs cross-fertilization benefited by entomophilous pollination, consequently increasing the genetic diversity.

The smallest genetic distance was observed between individuals 3 and 4, from Flona of Pacotuba, which are the individuals with the shortest geographical distance $(\sim 100 \mathrm{~m})$. The highest genetic dissimilarity value, between individual 9 from Flona of Pacotuba and individual 16 from PNHR Cafundó, was also related to the individuals' geographical distance. Although the fruits of $D$. nigra are flat, dry and long, favoring anemochoric dispersion and allowing the seeds to reach greater distances in relation to the mother plant, tree species are sometimes structured in subpopulations or demes, making them genetically more homogeneous, with a higher probability of kinship (Sebbenn, 2002; Gonçalves et al., 2019), corroborating what was observed in this study.
The partition of genetic dissimilarity and the formation of the dendrogram (Figure 2), demonstrated a close genetic relationship of some individuals from the Flona of Pacotuba (individuals 5 and 7) with the population from PNHR Cafundó. This result can be explained by the proximity of the CU's and the entomophilous pollination system of $D$. nigra, carried out mainly by bees (Silva and Costa, 20I4), which may be favoring the exchange of pollen between the individuals from the studied populations.

Notwithstanding, most individuals are genetically distinct, mainly within the Flona of Pacotuba and between the two populations. These individuals can be used as seed-trees for conservation and forest breeding programs, making possible the restoration and recovery of degraded areas, the connectivity of landscapes, and sustainable use of forest resources.

Regarding the lower genetic divergence among individuals from the PNHR Cafundó, which resulted in lower population diversity, it is necessary to adopt actions that increase the genetic variability in this forest fragment. As part of a strategy, we recommend the maintenance of the adult trees, who will serve as a source of seeds associated to the planting of seedlings with genetic material from other forest fragments with similar edaphoclimatic characteristics, or from individuals genetically distinct, such as those present in Flona of Pacotuba.

\section{Genetic structuring}

According to Wright's (1978) classification, the $\Phi_{\text {ST }}$ obtained $(0,14)$ indicated that the populations evaluated are moderately differentiated $\left(0.05<\Phi_{\text {ST }}<\right.$ $0.15)$. Furthermore, AMOVA revealed that the greatest genetic variation is within populations.

The finding of the greatest genetic variation within populations reinforces the hypothesis of the alleles exchange between them. However, the moderate genetic differentiation between populations indicates that they tend to become genetically more distant over the generations if the gene flow is interrupted. This is an important result since we have known that small and isolated populations are strongly influenced by genetic drift (Sebbenn et al., 201 I; Pence, 2016).

The number of migrants $\left(\mathrm{N}_{\mathrm{m}}\right)$ greater than the unit $\left(N_{m}=3.2 I\right)$, as we found in this study, indicates the occurrence of gene flow between populations (Wright, 195I). However, this estimate corresponds to the historical gene flow, referring to the interaction of populations in the past, when the actual adult trees settled (Kageyama et al., 2003). Nevertheless, the $N_{m}$ value found in this study can be considered low when 
compared to the values described for other tree species, such as 12.70 for Plathymenia reticulata (Souza et al., 2017) and 13.54 for Senefeldera verticillata (Vieira et al., 2018), which may be favoring the moderate genetic differentiation between populations.

Additionally, the structuring analysis carried out for the species indicated the formation of two groups (Figure 3). This result corroborates with the observed in the dendrogram (Figure 2). The color contrast between populations also confirms AMOVA's results, which indicate moderate genetic differentiation. Furthermore, it is possible to visualize the sharing of green color, where red is predominant and vice versa, showing a small exchange of alleles between populations.

In general terms, the structuring in two genetic groups well divided among the populations, the moderate genetic differentiation and the small occurrence of gene flow, are conflicting contexts. However, this can be explained by the exchange of alleles favored by only a part of individuals, such as those located at the edges of forest fragments. These results also indicate that populations are becoming structured, which can make them more susceptible to genetic erosion processes.

Therefore, we suggest to increase the connectivity of forest fragments using ecological corridors and, as previously mentioned, the planting of seedlings with contrasting genetic material. Such actions can prevent genetic degradation and may gradually restore the population effective size, especially for PNHR Cafundó.

\section{CONCLUSIONS}

The ISSR molecular markers are efficient in determining the levels of polymorphisms among individuals and in detecting the genetic diversity of $D$. nigra populations. There is a moderate to high genetic diversity for the species. However, most of the genetic diversity is influenced by the presence of genetically dissimilar individuals from the Flona of Pacotuba. Additionally, the occurrence of low gene flow, moderate genetic differentiation and structuring in two groups indicate that populations are becoming structured, which can affect the maintenance of populations in the long term.

\section{ACKNOWLEDGMENTS}

This work was carried out with the support of the Fundação de Amparo à Pesquisa e Inovação do Espírito Santo (FAPES), the Coordenação de Aperfeiçoamento de Pessoal de Nível Superior - Brasil (CAPES), the Universidade Federal do Espírito Santo (UFES) and the Núcleo de Pesquisa Científica e Tecnológica em Meio Ambiente, Silvicultura e Ecologia (NUPEMASE).

\section{REFERENCES}

AGUILAR, L. G.; LÓPEZ, A. M. S.; ACEITUNO, C. B.; ÁVILA, J. A. C.; GUERREIRO, J. A. L.; QUESADA, R. A. DNA source selection for downstream applications based on DNA quality indicators analysis. Biopreservation and Biobanking, v. 14, n. 4, p. 264-270, 2016.

AUGUIE, B.; ANTONOV, A. Miscellaneous Functions for “Grid” Graphics. R package version 2.3. 20I7. Available at: <https://cran.r-project.org/web/packages/gridExtra/ gridExtra $>$. Accessed in: April 24th 2020

CHESNOKOV, Y. V.; ARTEMYEVA, A. M. Evaluation of the measure of polymorphism information of genetic diversity. Agricultural Biology, v. 50, n. 5, p. 57I-578, 2015.

CRUZ, C. D. Genes software-extended and integrated with the R, Matlab and Selegen. Acta Scientiarum Agronomy, v. 38, n.4, p. 547-552, 2016.

DOYLE, J. J.; DOYLE, J. L. Isolation of plant DNA from fresh tissue. Focus, v. 12, p. 13-15, 1990.

EARL, D. A.; VONHOLDT, B. M. Structure Harvester: a website and program for visualizing Structure output and implementing the Evanno method. Conservation Genetics Resourch, v. 4, p. 359-36I, 2012.

EVANNO, G.; REGNAUT, S.; GOUDET, J. Detecting the number of clusters of individuals using the software Structure: a simulation study. Molecular Ecology, v. I4, n. 8, p. 26II-2620, 2005.

EXCOFFIER, L.; LISCHER, H. E. L. Arlequin suite ver 3.5: A new series of programs to perform population genetics analyses under Linux and Windows. Molecular Ecology Resources, v. 10, p. 564-567, 2010.

FALUSH, D.; STEPHENS, M.; PRITCHARD, J. K. Inference of population structure using multilocus genotype data: dominant markers and null alleles. Molecular Ecology Notes, v. 7, n. 4, p. 574-578, 2007.

FILIPPOS, A. Conservation and monitoring of tree genetic resources in temperate forests. Current Forestry Reports, v. 2, n. 2, p. I19-129, 2016.

GALILI, T.; BENJAMINI, Y.; SIMPSON, G.; JEFFERIS, G.; GALLOTA, M.; RENAUDIE, J.; HORNIK, K.; LIGGES, U.; SPIESS, A.; HORVATH, S.; LANGFELDER, P.; LOO, M. V. D.; VRIES, A.; GU, Z.; MA, J.; G, K.; HUMMEL, M.; CLARK, C.; GRAYBUCK, L.; HO, B.; PERREAULT, S.; HENNIG, C.; BRADLEY, D. Extending 'dendrogram' Functionality in $\mathbf{R}$. $R$ package version I.13.4. 2020. Available at: $<$ https://cran.r-project.org/web/packages/dendextend/ dendextend >. Accessed in: April 24th 2020. 
GINWAL, H. S.; MAURYA, S. S.; CHAUHAN, P. Genetic diversity and relationship between cultivated clones of Dalbergia sissoo of wide geographical origin using RAPD markers. Journal of Forestry Research, v. 22, n. 4, p. 507-517, 2011.

GOIS, I. B.; FERREIRA, R. A.; SILVA-MANN, R. Variabilidade genética em populações naturais de Cassia grandis $\mathrm{L}$. f. Floresta e Ambiente, v. 25, n. 4, p. I-10, 2018.

GONÇALVES, A. L.; GARCÍA, M. V.; HEUERTZ, M.; GONZÁLEZ-MARTÍNEZ, S. C. Demographic history and spatial genetic structure in a remnant population of the subtropical tree Anadenanthera colubrina var. cebil (Griseb.) Altschul (Fabaceae). Annals of Forest Science, v. 76, n. 18, p. I-16, 2019.

HAMRICK, J. L. Tropical breeding systems: one and done? Heredity, v. I09, n. 6, p. 330-331, 2012.

ICMBIO - INSTITUTO CHICO MENDES DE CONSERVAÇÃO DA BIODIVERSIDADE. Plano de Manejo da Floresta Nacional de Pacotuba, localizada no estado do Espirito Santo. Vila Velha, ES, 20I I.

IUCN - INTERNATIONAL UNION FOR CONSERVATION OF NATURE. The IUCN Red List of Threatened Species. Version 2018.I, 2020. Available at: <https:// www.iucnredlist.org/species/32985/86221 269>. Accessed in: April 24th 2020.

JAKOBSSON, M.; ROSENBERG, N. A. Clumpp: a cluster matching and permutation program for dealing with label switching and multimodality in analysis of population structure. Bioinformatics, v. 23, p. I80I-I806, 2007.

JUCHUM, F. S.; LEAL, J. B.; SANTOS, L. M.; ALMEIDA, M. P.; AHNERT, D.; CORREAA, R. X. Evaluation of genetic diversity in a natural rosewood population (Dalbergia nigra Vell. Allemão ex Benth) using RAPD markers. Genetics and Molecular Research, v. 6, n. 3, p. 543-553, 2007.

KAGEYAMA, P. Y.; SEBBENN, A. M.; RIBAS, L. A.; GANDARA, F. B.; CASTELLE, M.; PERECIM, M. B.; VENCOVSKY, R. Diversidade genética em espécies arbóreas tropicais de diferentes estágios sucessionais por marcadores genéticos. Scientia Forestalis, n. 64, p. 93-107, 2003.

KASSAMBARA, A. 'ggplot2' Based Publication Ready Plots. R package version 0.4.0. 2020. Available at: < https://cran.r-project.org/web/packages/ggpubr/ggpubr>. Accessed in: April 24th 2020.

KASSAMBARA, A.; MUNDT, F. Factoextra: Extract and Visualize the Results of Multivariate Data Analyses. $\mathrm{R}$ package version I.0.5. 2017. Available at: <https:// CRAN.R-project.org/package $=$ factoextra $>$. Accessed in: April 24th 2020.

LIMA, H.C. Dalbergia in Lista de Espécies da Flora do Brasil. Jardim Botânico do Rio de Janeiro, 20I5. Available at: <http://floradobrasil.jbrj.gov.br/jabot/floradobrasil/ FB229|5>. Accessed in: April 24th 2020.
MACEDO, M.; DEFRIES, R. S.; MORTON, D. C.; STICKLER, C. M.; GALFORD, G. L.; SHIMABUKURO, Y. E. Decoupling of deforestation and soy production in the southern Amazon during the late 2000s. Proceedings of the National Academy of Sciences, v. 109, n. 4, p. I34I-1346, 2012.

MAECHLER, M.; ROUSSEEUW, P.; STRUYF, A.; HUBERT, M.; HORNIK, K.; STUDER, M.; ROUDIER, P.; GONZALEZ, J.; KOZLOWSKI, K.; SCHUBERT, E.; MURPHY, K. Finding Groups in Data": Cluster Analysis Extended Rousseeuw et al. R package version 2.1.0. 2019. Available at: <https://cran.r-project.org/web/packages/cluster/ cluster>. Accessed in: April 24th 2020.

MANGARAVITE, E.; SILVEIRA, T. C.; HUAMÁN-MERA, A.; OLIVEIRA, L. O.; MUELLNER-RIEHL, A. N.; SCHNITZLER, J. Genetic diversity of Cedrela fissilis (Meliaceae) in the Brazilian Atlantic Forest reveals a complex phylogeographic history driven by Quaternary climatic fluctuations. Journal of Systematics and Evolution, n. 6, v. 57, p. 655-669, 2019.

MARTINELLI, G.; MORAES, M. A. Livro Vermelho da Flora do Brasil. Rio de Janeiro: Andrea Jakobsson: Instituto de Pesquisas Jardim Botânico do Rio de Janeiro, 20 I3, I I00p.

MARTINS, K.; KIMURA, R. K.; FRANCISCONE, S. G.; KAINER, K.; CHRISTIANINI, A. V. The role of very small fragments in conserving genetic diversity of a common tree in a hyper fragmented Brazilian Atlantic forest landscape. Conservation genetics, v. I7, n. 3, p. 509-520, 2016.

CAMPANILI, M.; SCHAFFER, W. B. Mata Atlântica: Manual de adequação ambiental. Brasília: Ministério do meio ambiente; Secretaria de biodiversidade e florestas, 2010, 96p.

MOJEMA, R. Hierarchical grouping methods and stopping rules: an evaluation. The Computer Journal, v. 20, p. 359-363, 1977.

OKSANEN, J.; BLANCHET, F. G.; FRIENDLY, M.; KINDT, R.; LEGENDRE, P.; MCGLINN D.; MINCHIN, P.R.; O'HARA, R. B.; SIMPSON, G. L.; SOLYMOS, P.; STEVENS, M. H. H.; SZOECS E.; WAGNER, E. Vegan: Community Ecology Package. $\mathrm{R}$ package version 2.4-5. 2018. Available at $\quad<$ https://CRAN.R-project.org/package=vegan $>$. Accessed in: April 24th 2020.

PENCE, C. H. Is genetic drift a force? Synthese, v. 194, p. 1967-1988, 2016.

POTTER, K. M.; JETTON, R. M.; BOWER, A.; JACOBS, D. F; HIPKINS, V.D.; WETWOOD, M. Banking on the future: Progress, challenges and opportunities for the genetic conservation of forest trees. New Forests, v. 48, p. I53-I80, 2017.

R CORE TEAM. R: A language and environment for statistical computing. $R$ Foundation for Statistical Computing, Vienna, Austria, 2016.

RIBEIRO, A. R.; RAMOS, A. C. S.; FILHO, J. P. L.; LOVATO, M. B. Genetic Variation in Remnant Populations of Dalbergia nigra (Papilionoideae), an Endangered Tree from the Brazilian Atlantic Forest. Annals of Botany, v. 95, p. II7I-II77, 2005. 
RIBEIRO, N. P.; SANCHES, C. C.; OLIVEIRA, M. A. C.; COSTA, B. R. Biodiversidade e conservação de recursos genéticos de espécies arbóreas. Multitemas, v. 2I, n. 50, p. 31-49, 2016.

ROSENBERG, N. A. Distruct: A program for the graphical display of population structure, version I.I. Molecular Ecology, v. 4, p-137-138, 2004.

SEBBENN, A. M. Número de árvores matrizes e conceitos genéticos na coleta de sementes para reflorestamentos com espécies nativas. Revista do Instituto Florestal, v. 14, n. 2, p. II5-132, 2002.

SEBBENN, A. M.; CARVALHO, A. C. M.; FREITAS, M. L. M.; MORAES, S. M. B.; GAINO, A. P. S. C.; SILVA, J. M.; JOLIVET, C.; MORAES, M. L. T. Low levels of realized seed and pollen gene flow and strong spatial genetic structure in a small, isolated and fragmented population of the tropical tree Copaifera langsdorffii Desf. Heredity, v. 106, p. 134-145, 201 I.

SILVA, A. G.; COSTA, L. G. Germinação, morfologia de frutos, sementes e plântulas de jacarandá-da-Bahia (Dalbergia nigra (Vell.) Fr. All. ex. Benth.). Enciclopédia Biosfera, v. 10, n. I8, p. I87I-1879, 2014

SOUZA, L. C.; SILVA JÚNIOR, A. L.; SOUZA, M. C.; KUNZ, S. H.; MIRANDA, F. D. Genetic diversity of Plathymenia reticulata Benth in fragments of Atlantic Forest in southeastern Brazil. Genetics and Molecular Research, v. 16, p. I-13, 2017.

TAPIA-ARMIJOS, M. F;; HOMEIER, J.; ESPINOSA, C. I.; LEUSCHNER, C.; CRUZ, M. Deforestation and forest fragmentation in South Ecuador since the 1970s-losing a hotspot of biodiversity. PloS one, v. 10, n. 9, 2015.

TEMPLETON, A. R. Genética de populações e teoria microevolutiva. Ribeirão Preto -SP: Sociedade Brasileira de Genética, 20II, 705p.
VIEIRA, A. A. R.; SILVA JÚNIOR, A. L.; SOUZA, L. C.; MIRANDA, F. D.; FERREIRA, M. F. S.; CALDEIRA, M. V. W. Genetic structure and diversity of Senefeldera verticillata (Euphorbiaceae) in semideciduous seasonal forest fragments. Genetics and Molecular Research, v. 17, n. 3, p. I-II, 2018.

WANG, B. Y.; SHI, L.; RUAN, Z. Y.; DENG, J. Genetic diversity and differentiation in Dalbergia sissoo (Fabaceae) as revealed by RAPD. Genetics and Molecular Research, v. 10, n. I, p. $114-120,2010$.

WEILER, R. L.;BRUGNARA, E.C.;SCHWARZ,S. F.;BASTIANEL, M.; MACHADO, M. A.; SCHIFINO-WITTMANN, M. T. Caracterização molecular de uma progênie de tangerineira 'Clementina Fina' e 'Montenegrina'. Ciência Rural, v. 40, n. 7, p. 1523-1529, 2010.

WILKE, C. O. Streamlined Plot Theme and Plot Annotations for 'ggplot2'. R package version I.0.0. 2019. Available at: $<$ https://cran.r-project.org/web/packages/cowplot/cowplot>. Accessed in: April 24th 2020.

WRIGHT, S. Evolution and the genetics of populations: variability within and among natural populations. University of Chicago press, Chicago, IL, USA, 1978.

WRIGHT, S. The Genetical Structure of Populations. Annals of Eugenics, v. 15, p. 323-354, 1951.

YEH, F. C.; BOYLE, T. J. B. Population genetic analysis of codominant and dominant markers and quantitative traits. Belgian Journal of Botany, v. 129, p.156-157, 1997.

YULITA, K. S.; ATIKAH, T. D.; WARDANI, W.; SULITA. Unraveling genetic variations of Dalbergia latifolia (Fabaceae) from Yogyakarta and Lombok Island, Indonesia. Biodiversitas, v. 2I, n. 2, p. 833-84I, 2020. 